\title{
Growth Performance and its Sources Vis-à-Vis Minimum Support Price of Cotton in Telangana State
}

\author{
Aldas Janaiah*, A. Abhilasha and K. Shireesha \\ Agricultural Extension, Agricultural College (PJTSAU), Aswaraopet, Telangana, India \\ *Corresponding author
}

\begin{tabular}{|l|}
\hline Ke y w o r d s \\
$\begin{array}{l}\text { Cotton, Growth, } \\
\text { MSP in Telangana }\end{array}$ \\
\hline Article Info \\
\hline $\begin{array}{l}\text { Accepted: } \\
\text { 07 November } 2020 \\
\text { Available Online: } \\
\text { 10 December } 2020\end{array}$ \\
\hline
\end{tabular}

\begin{abstract}
A B S T R A C T
The core objective of the study is to exam the growth performance and its sources of cotton vis-a-vis minimum support price over the past 20 years, using secondary data. A linear regression model, simple tabular analysis, and arithmetic measures such as averages, percentages, and other statistical methods were used. Growth performance was analysed for the country as a whole (national level), and for the state of Telangana (state level). Similar analysis was carried out for a leading cotton producing district, Adilabad of Telangana to examine growth performance at district level in relation to national/state level trends. At national level, yield improvement has contributed to the extent of twothirds of production growth over the past two decades. Results however indicate the share of area expansion to production growth of cotton in Telangana state as well as in Adilabad of the state was about three-fourths, and rest of one-fourth was due to yield improvement during the period 2001-2019. It was observed that a positive effect of new technological innovations that was made available to the farmers after 2001, especially Bt cotton hybrids on area growth in cotton. The Minimum Support Price of cotton has also become an attractive factor for expansion of cotton area. Farmers in Telangana have received higher market price of cotton produce, than MSP in 13 years between 2001 and 2019. Findings suggest that a remunerative MSP with higher rate of increase than present MSP growth rate, and an assured procurement by CCI are key policy options for sustaining farmers; profitability of cotton.
\end{abstract}

\section{Introduction}

India accounts for about $37 \%$ of global cotton area. However, India's share in the global cotton is only about $25 \%$, primarily due to low yield of cotton in India. Nearly $25 \%$ of the total global fiber production is cotton (FAOSTAT, 2019). India is one of the largest producers as well as exporters of cotton yarn. Cotton yarn and fabrics exports accounts for about 23 per cent of India's total textiles and apparel exports. It plays a major role in sustaining the livelihood of an estimated 5.8 million cotton farmers in India and 40- 50 million people engaged in related activities such as cotton processing and trade.

In India, the top three Cotton producing states are Maharashtra, Gujarat and Telangana. Cotton crop in Telangana is widely known 
among farmers as "WHITE GOLD" due to its attractive profitability in the event of bumper yield. In particular, Cotton crop has been expanded significantly in the state after introduction of $\mathrm{Bt}$ cotton that reduced the biological risks of pest incidence in cotton. Thus, large area of millets, pulses, and oilseed crops were diverted to cotton crop over the past 20 years, and as a result cotton crop has emerged as the leading crop in the state. It is important to note that cotton production has increased in the state by many folds over the past 20 years, primarily due to increased area under cotton, and small increase in yield.

However having noted significant expansion of cotton not only in Telangana state but also in other leading states, India is experiencing its biggest wave of suicides among cotton farmers. Some observers have linked the deaths to the introduction of costly genetically modified seeds, fertilizers and insecticides. Many farmers turn to loan -sharks to pay for these items, however unfavorable weather conditions, or even a mere dip in the global price of cotton, can spell disaster for growers. (3- Bill and Melinda Gates 2019).It is widely reported that the highest number of farmers' suicides were among those farmers who grow predominantly cotton. Indebtedness is highest among cotton farmers in the state. Although production related constraints were almost addressed in cotton through technological intervention, marketing constraints have emerged serious impeding issues for cotton farmers in the recent past. Increased cotton production over the past 20 years has also brought pressure upon the marketing system of cotton. Despite considerable increase in Minimum Support Price of cotton and market interventions by both state and central governments over the period, farmers quite often sell the cotton output at lower market price than MSP, especially in the years of bumper production. Farmers get MSP if cotton is marketed through CCI. In addition, ginning mills are other major buyers of cotton. Farmers may get MSP or more or less of it, depending upon market forces at that point of time. There are occasions when farmers get farm-gate price, which higher than MSP, and even much lower than MSP in some years.

This paradoxical situation of cotton raises two issues, (a) Have whether increased cotton production was due to area expansion or yield increases or both effects over the period? and (b) Are farmers getting remunerative and minimum support price?

Adilabad is the largest cotton producing district in Telangana, accounting for about $10 \%$ of the state's cotton area. Cotton is grown in district, largely under rain fed conditions. Cotton occupies a very large portion of the net cropped area in the district. Cotton provides a major livelihood to rural people in the district, due to presence of cotton based small scale industries in rural areas.

In view of the emerging paradoxical scenario of cotton cultivation in the state, An attempt has been made in the study to identify the relative importance of sources of, production growth (area and yield) of cotton.

The specific objectives of (a) to measure and analyse sources of the growth of cotton production at national, state and as well as at district level over the past 20 years, and (b) to assess the outreach of Minimum Support Price vis-à-vis growth performance of cotton production in the state.

\section{Materials and Methods}

The study is based on the relevant secondary data collected from different published sources of the Government of India, Telangana government, Directorate of 
Economics and Statistics, State Department of Agriculture, Cotton Corporation of India Limited, etc. The data on area, production and yield of cotton crop at national and state level have been collected from sources like Economic Survey, Agricultural Statistics at a Glance, data published by Directorate of Economics and Statistics, Department of Agriculture \& Co-operative - Government of India. The data pertaining to MSP, channels of marketing, area, area, production, yield, etc., have been collected from District Agriculture office Adilabad, Market yard committee, Chief planning and statistical office Adilabad.

The growth performance of cotton at national, state and district levels is analyzed for the period, 2000-01 to 2018-19. Accordingly, secondary data of the relevant variables for the past 20 years were collected from various sources.

A comprehensive and focused analytical approach was followed to analyse the data keeping in view the key objectives of the research.A simple tabular analysis, arithmetic measures such as averages, percentages, etc. wereused.To calculate the compound growth rates (CGR) of area, production and yield of cotton, the following log linear regression was used:

$\log Y=a+b t$

Where $\log \mathrm{Y}=\log$ value of the dependent variable for which growth rate is calculated, $t$ $=$ time period, independent variable taking the values $1,2,3, \ldots \ldots \ldots \ldots \ldots, \mathrm{n}$,

$\mathrm{a}=$ intercept,

$b=$ the regression co-efficient of ' $\log Y$ ' on t.

The CGAR is computed by multiplying "b" values with 100. A t-test is used to test the significance levels of CGAR.
Sum of growth rates in area and yield is growth rate in production. Accordingly, share of growth in area and yield in the production growth was estimated.

\section{Results and Discussion}

The core objective of this study is to examining the growth performance of cotton vis-a-via minimum support of cotton over the past 20 years. Growth performance was analysed for the country as a whole (national level), and for the state of Telangana (state level). In addition, similar analysis was carried out for a leading cotton producing district, Adilabad of Telangana to examine growth performance at district level in relation to national/state level trends.

\section{Growth performance: Trends and sources of production growth}

Cotton is grown in about 12 million hectares with 6.2 million tonnes of production in India during 2018-19 (MoA \& FW, 2019). Area planted to cotton in the World is almost stagnated at about 32 million ha since 2000-1. However, the area under cotton has increased by about $50 \%$ over the past two decade; from 8.53 million ha in 2000-01 to nearly 12 million ha by 2019 (Table 1). The global cotton yield has increased from $586 \mathrm{~kg}$ of lint per ha to $750 \mathrm{~kg}$ of lint per ha during this period (FAO, 2019). India's share in the World's cotton area is nearly one-third while cotton production is only one-fourth of the global output in 2019.

This implies that the average cotton yield in India is only about two-thirds of World's average. From table 1, it is clear that the incremental increase in the production (39.3\%) was higher than the incremental increase in area (18.2\%) between 2001 and 2019. This trend shows that the incremental increase in yield was much higher than the 
incremental increase in area over the past 20 years. This could be due to a positive effect of new technological innovations that were made available to the farmers after 2001.

The Minimum Support Price of cotton has also became an attractive factor for expansion of cotton area in India, as farmers always respond positively to higher output prices in area allocation. In addition, increased market intervention by Cotton Corporation of India Limited and increased export opportunities of cotton could have also considerably contributed to substantial growth in cotton area.

Table.1 Incremental increases in area, production and yield of cotton in India, 2001 to 2019

\begin{tabular}{|l|c|c|c|c|}
\hline \multirow{2}{*}{ Particulars } & $\mathbf{2 0 0 0 - 0 1}$ & \multicolumn{3}{|c|}{ Incremental increases between (\%) } \\
\cline { 3 - 5 } & & $2000-01$ to & $2009-10$ to & $2000-01$ to \\
& & $2009-10$ & $2018-19$ & $2018-19$ \\
\hline Area & 8.53 & 18.76 & 17.28 & 39.27 \\
\hline Production & 1.68 & 152.31 & 45.80 & 267.86 \\
\hline Yield & 190.00 & 112.11 & 27.54 & 170.53 \\
\hline
\end{tabular}

Note: Area (in million ha); Production (in million tonnes); Yield (Kg/ha)

Data Source: Ministry ofAgriculture and Farmers; Welware, GOI (various reports)

Table.2 Incremental increases in area, production and yield of cotton in Telangana, 200-01 to 2018-19

\begin{tabular}{|l|c|c|c|c|}
\hline \multirow{2}{*}{ Particulars } & $\mathbf{2 0 0 0 - 0 1}$ & \multicolumn{3}{|c|}{ Incremental increases in Percentages } \\
\cline { 3 - 5 } & & $2000-01$ to & $2009-10$ to & $2000-01$ to \\
& & $2009-10$ & $2018-19$ & $2018-19$ \\
\hline Area & 0.63 & 130.13 & 58.53 & 191.90 \\
\hline Production & 0.17 & 25.05 & 64.61 & 279.01 \\
\hline Yield & 273.89 & 3.83 & 29.84 \\
\hline
\end{tabular}

Area (in million ha) , Production(in million tonnes); Yield (Kg/ha)

Data Source : DES, Government of Telangana (various reports)

Table.3 Incremental increases in area, production and yield of Cotton in Adilabad district, 200001 to $2018-19$

\begin{tabular}{|l|c|c|c|c|}
\hline Particulars & $\mathbf{2 0 0 0 - 0 1}$ & \multicolumn{3}{|c|}{ Incremental increases in Percentages } \\
\cline { 3 - 5 } & & $2000-01$ to & $2009-10$ to & $2000-01$ to \\
& & $2009-10$ & $2018-19$ & $2018-19$ \\
\hline Area & 0.17 & 65.67 & 25.43 & 107.80 \\
\hline Production & 0.06 & 73.54 & 64.31 & 185.13 \\
\hline Yield & 326.28 & 4.75 & 30.99 & 37.21 \\
\hline
\end{tabular}

Area (in million ha), Production(in million tonnes); Yield (Kg/ha)

Data Source: DES, Government of Telangana (various reports) 
Table.4 Compound annual growth rate (CAGR) in area, production and yield of Cotton in India, Telangana State and Adilabad district, 2000-01 to 2018-19 (\%/year)

\begin{tabular}{|l|c|c|c|}
\hline Particulars & $\begin{array}{c}\text { India } \\
\text { (Percentage/year) }\end{array}$ & $\begin{array}{c}\text { Telangana State } \\
\text { (Percentage/year) }\end{array}$ & $\begin{array}{c}\text { Adilabad District } \\
\text { (Percentage/year) }\end{array}$ \\
\hline Area & 1.18 & 3.25 & 2.18 \\
\hline Production & $* * *$ & $* * *$ & $* * *$ \\
\hline & 3.38 & 4.25 & 3.35 \\
\hline Yield & $* * *$ & $* * *$ & $* * *$ \\
\hline & 2.22 & 0.99 & 1.16 \\
\hline
\end{tabular}

*** Significant at $1 \%$ level; ** Significant at $5 \%$ level; * Significant at $10 \%$ level

Source: Authors' estimates based on times-series data

Table.5 Compound annual growth rate in Minimum Support Price of cotton in India, 2001 to 2019

\begin{tabular}{|c|c|}
\hline Period & CAGR(Percentage/year) \\
\hline $\mathbf{2 0 0 0 - 0 1}$ to 2009-10 & $2.19 * * *$ \\
\hline $\mathbf{2 0 0 9 - 1 0}$ to 2019-20 & $2.54 * * *$ \\
\hline $\mathbf{2 0 0 0 - 0 1}$ to 2019-20 & $2.77 * * *$ \\
\hline$* * *$ & Significant at $1 \%$ level; $* *$ Significant at $5 \%$ level, $*$ Significant at $10 \%$ level \\
\hline
\end{tabular}

Table.6 Difference between MSP and farm harvest prices received by the farmers in Adilabad district, 2000-01 to 2019-20

\begin{tabular}{|l|l|l|c|}
\hline Year & MSP & Average FHP & Percentage difference between MSP minus FHP \\
\hline $\mathbf{2 0 0 0 - 0 1}$ & 1825 & 2110.50 & -15.64 \\
\hline $\mathbf{2 0 0 1 - 0 2}$ & 1875 & 1750.00 & 6.67 \\
\hline $\mathbf{2 0 0 2 - 0 3}$ & 1875 & 2200.00 & -17.33 \\
\hline $\mathbf{2 0 0 3 - 0 4}$ & 1925 & 2480.00 & -28.83 \\
\hline $\mathbf{2 0 0 4 - 0 5}$ & 1960 & 1877.50 & 4.21 \\
\hline $\mathbf{2 0 0 5 - 0 6}$ & 1980 & 1835.00 & 7.32 \\
\hline $\mathbf{2 0 0 6 - 0 7}$ & 1990 & 2050.00 & -3.02 \\
\hline $\mathbf{2 0 0 7 - 0 8}$ & 2050 & 2550.00 & -24.39 \\
\hline $\mathbf{2 0 0 8 - 0 9}$ & 3000 & 2300.00 & 23.33 \\
\hline $\mathbf{2 0 0 9 - 1 0}$ & 3000 & 3175.00 & -5.83 \\
\hline $\mathbf{2 0 1 0 - 1 1}$ & 3000 & 4550.00 & -51.67 \\
\hline $\mathbf{2 0 1 1 - 1 2}$ & 3300 & 4000.00 & -21.21 \\
\hline $\mathbf{2 0 1 2 - 1 3}$ & 3900 & 3975.00 & -1.92 \\
\hline $\mathbf{2 0 1 3 - 1 4}$ & 4000 & 4300.00 & -7.50 \\
\hline $\mathbf{2 0 1 4 - 1 5}$ & 4050 & 3935.00 & 2.84 \\
\hline $\mathbf{2 0 1 5 - 1 6}$ & 4100 & 4400.00 & -7.32 \\
\hline $\mathbf{2 0 1 6 - 1 7}$ & 4160 & 4500.00 & -8.17 \\
\hline $\mathbf{2 0 1 7 - 1 8}$ & 4320 & 5587.50 & -29.34 \\
\hline $\mathbf{2 0 1 8 - 1 9}$ & 5450 & 5425.00 & 0.46 \\
\hline $\mathbf{2 0 1 9}$ & 5550 & 4925.00 & 11.26 \\
\hline $\mathbf{D}$ & & & \\
\hline
\end{tabular}

Data Source :DES, Government of Telangana (various reports) 
A critical assessment of the growth performance of cotton in Telangana state over the past 20 years has shown a much more impressive trend than what was observed at all India level. Cropped area planted to cotton in Telangana state is about 1.85 million ha, which is about $15 \%$ of India's cotton area. But Telangana state's share in India's cotton production is about $30 \%$, largely due to higher yield of cotton in the state as compared to all India average (DES, 2019). Table 2 summarizes the incremental increases in area, production and yield of cotton in Telangana over the past 20 years. Area planted to cotton crop has increased from about 0.63 million ha to 1.85 million ha, nearly three folds between 2001 and 2019, i.e. about $200 \%$ increase in 2019 over 2001. Incremental increase in cotton production between 2001 and 2019 was about $280 \%$. This clearly explains that yield increase by about $30 \%$ between 2001 and 2019 contributed to higher production increases than the area increases during this period. The introduction of Bt cotton hybrids, market intervention and attractive MSP could have played a significant role in boosting cotton area and production in the state.

Adilabad district is one of the traditional cotton belts in Telangana state, bordering Vidharbha region of Maharashtra. Cotton is grown in about 3 lakh hectares with 1.8 lakh tonnes of production in the district during 2018-19. Share of Adilabad (undivided district) in the state's area and production of cotton was about $20 \%$ and $18 \%$ respectively. Cotton area and production between 2001 and 2019 increased significantly by about double and triple times respectively (table 3 ). In Adilabad district, cotton yield has increased substantially between 2010 and 2019, as shown in table 3 .

Table 4 summarized the estimates of compound annual growth rates (CAGRs) in area, production and yield of cotton at all
India level, state level and in the selected district for the period, 2001 to 2019. In India, cotton production has increased at a compound growth rate of $3.4 \%$ per year over the past 20 years. Two-thirds of production growth was contributed by yield improvement, as out of $3.4 \%$ production growth, yield growth was $2.2 \%$. The remaining one-thirds of production growth was accounted for area growth at all India level (Table 4).

On contrary in Telangana, area expansion at the compound rate of $3,25 \%$ per year was a major contributor to the production growth of about $4.25 \%$ per year during the period, 2001 to 2019. Large area under millets, pulses and oilseed crops was diverted to cotton crop in Telangana over the past twenty years. Thus, cotton area has significantly increased at the cost of food crops in Telangana. Yield growth of cotton in Telangana was lower than the yield growth registered at national level during 2001 to 2019. Similar trend was observed for Adilabad district.

From Table 4, it is inferred that the growth area planted to cotton was a major source of production growth to the extent of threefourths in Telangana state as well as in Adilabad district. At national level, yield improvement has contributed to the extent of two-thirds of production growth.

\section{Growth in MSP}

Minimum Support Price (MSP) policy is an important policy instrument to influence the farmers' decision on area allocation among different crops, In general, the MSP will be announced by the Government of India at the pre-sowing time every year based on the recommendation of the Commission for Agricultural Costs and Prices (CACP). Keeping in view of the commendable increase in cotton area in the country as well as in 
Telangana state over the past 20 years, an attempt has been made in this study to examine growth in MSP vis-a-vis area growth. Table 5 shows an impressive growth in MSP (nominal prices) of cotton at about $2.8 \%$ per year during 2001 to 2019 while cotton area has increased at $2.2 \%$ per year in the country during same period (Table 4). Similarly, growth rate in MSP increased during 2010-2019, which was higher than the growth rate of MSP registered during previous decade (2001-2009). The same trend is noticed in the growth of cotton area in the country (Table 4). Therefore, it may be concluded from table 5 that MSP has a strong positive effect on cotton area in the country.

Another key issue related to whether farmers at district level are getting MSP for cotton. Whether MSP is higher than farm harvest price (FHP) which farmers actually receive for of cotton? The MSP and FHP of cotton was compared for Adilabad district a case to draw meaningful conclusion on this issue.

Farm harvest price (FHP) is the actual market price at which farmers sell cotton produce. FHP may be higher or lower than MSP, mainly depend upon level of cotton production during that year. Table 6 presents the gap between MSP and FHP of cotton over the past twenty years, registered in Adilabad district of Telangana. It is observed that FHP of cotton was higher than MSP in 13 years, out of past twenty years. This implies that farmers have received higher market price of cotton produce, than MSP in 13 years between 2001 and 2019. Farmers generally gets higher price than MSP, when they sell cotton produce in the open markets and to ginning millers especially in the years of lower production. In normal years, farmers get MSP only, as they sell cotton produce to Cotton Corporation of India (CCI) outlets especially in the event of bumper production. Thus, farmers' preference of marketing channel depends on price offered and level of crop production.

In conclusion the cotton is grown in about 12 million hectares with 6.2 million tonnes of production in India during 2018-19. India's share in the World's cotton area is nearly onethirds. Average cotton yield in India is only about two-thirds of World's average yield. The incremental increase in production was higher than the incremental increase in area at national level, as well as at Telangana state level and in Adilabad district of Telangana between 2001 and 2019. This new technological innovations that were made available to the farmers after 2001, especially Bt cotton hybrids and the Minimum Support Price of cotton could have contributed for expansion of cotton area, as farmers always respond positively to new innovations and higher output prices in area allocation. At national level, yield improvement has contributed to the extent of two-thirds of production growth over the past two decades. On contrary, area expansion under cotton was a major source of increased production growth to the extent of three-fourths in Telangana state as well as in Adilabad district.

MSP (nominal prices) of cotton has increased at about compound growth rate of $2.8 \%$ per year during 2001 to 2019 while cotton area has increased at $2.2 \%$ per year in the country during same period.. The MSP has a strong positive effect on cotton area in the country as well as in Telangana state. Farm harvest price (FFHP) of cotton was higher than MSP in 13 years out of past twenty years.

\section{References}

Aditya, K.S. and Subash, S.P. and Praveen, K.V. and Nithyashree, M.L. and Bhuvana, N. and Sharma, Akriti. Awareness about minimum support 
price and its impact on diversification decision of farmers in India (September 4, 2017). Asia \& the Pacific Policy Studies, Vol. 4, No. 3, pp. 514-526, September 2017, Crawford School of Public Policy, The Australian National University, Available at SSRN: https://ssrn.com/abstract=30615 64.

Amod, S. 2015. Growth and Variability in Area, Production and Yield of Cotton Crop, International Journal of Agriculture Innovations and Research Volume 4, Issue 3, ISSN (Online) 23191473. Available at http://www.ijair.com/administrator/com ponents/com_jresearch/files/publication s/IJAIR_1698_Final.pdf.

Geetha, R. S. and Mahesh, V.2019. Minimum Support Prices (MSP) and Its Influence on Cotton Farming in India. Asian Journal of Agricultural Extension, Economics \& Sociology.

Kallur and Vastrad. 2002. Working of the regulated markets with particular reference to cotton market township paper presented in the $62^{\text {nd }}$ annual conference of ISAE held at New-Delhi.

Kundu, S.C. and Rani, S. 2004. Entrepreneurial orientation of aspiring managers: a study. International Journal of Management and Enterprise Development, 1(3), pp. 233-250.

Namami, G and Singh, S. 2018. An Analysis of Problems and Constraints Faced by Farmers in Marketing of Agricultural Produce in Punjab. Department of Economics and Sociology, Economic Affairs, Vol. 63, No. 3, pp. 671-678, September 2018.

Parikh and Singh, S. 2007. Awareness about Minimum Support Price and Its Impact on Diversification Decision of Farmers in India. https://doi.org/10.1002/app5.197.

Suresh Kumar and Chahal, S.S. 2007. Constraints in the production and marketing of maize in Punjab. Agric. Update, 5(1\&2): 228-236.

Shreedevi, N. and Ashok, P. 2017. Growth and instability in area, production and different crops in Bengaluru division. International Journal of Agriculture, Environment and Biotechnology.

Vastrad, R.V. 1996. Marketing of cotton in Tungabhadra ayacut area unpublished $\mathrm{Ph} . \mathrm{D}$ thesis submitted to Gulbarga University Gulbarga-273.

\section{How to cite this article:}

Aldas Janaiah, A. Abhilasha and Shireesha, K. 2020. Growth Performance and its Sources Visà-Vis Minimum Support Price of Cotton in Telangana State. Int.J.Curr.Microbiol.App.Sci. 9(12): 599-606. doi: https://doi.org/10.20546/ijcmas.2020.912.071 